\title{
CARBONYL FORMATION IN ERYTHROCYTE MEMBRANE PROTEINS DURING AGING IN HUMANS
}

\author{
Rashmi Jha, Syed Ibrahim Rizvi*
}

Department of Biochemistry, University of Allahabad, Allahabad 211002, India

E-mail: sirizvi@gmail.com

Received: October 31, 2010; Accepted: December 8, 2010

Key words: Aging/Protein Carbonyl/Oxidative Stress/Erythrocytes

Background. Studies have shown that oxidative stress increases with increasing human age. Protein carbonyl accumulation is an indicator of oxidative damage to proteins during aging in cells and tissues. The present study is focused on the relationship between human age and protein oxidation in erythrocyte membranes in a healthy Indian population.

Materials and Methods. The sample included healthy human subjects $(n=49)$ between the ages of 17 to 80 years. Their blood was collected and assayed spectrophotometrically for oxidative protein damage in terms of protein carbonyls and plasma antioxidant capacity in terms of FRAP.

Results. Protein carbonyl content was found to increase in an age-related pattern indicating an increase in oxidative protein damage in older subjects $(\mathrm{p}<0.0001, \mathrm{r}=0.8269)$. There was also a significant negative correlation between protein oxidation and plasma antioxidant capacity measured in terms of ferric reducing antioxidant potential (FRAP) values $(\mathrm{p}<0.0001 ; \mathrm{r}=-0.8695)$.

Conclusion. Our results substantiate the occurrence of oxidative stress during human aging. Elevated erythrocyte membrane carbonyl levels found with increasing age in this study may be viewed as a biomarker for aging.

\section{INTRODUCTION}

Oxidative stress caused by the presence of free radicals or radical-generating agents in concentrations that overwhelm natural radical-blocking or scavenging antioxidant mechanisms, is the core of the free radical theory of aging $^{1,2}$. This theory provides the best explanation of the aging process. Studies in humans and other organisms have shown that indices of oxidative stress increase with advancing age ${ }^{3,4}$.

Normal cell functioning depends upon oxygen as the final acceptor of electrons in mitochondrial electron transport, but the process also generates toxic metabolites. Reactive oxygen species (ROS) leak from mitochondria into the cytoplasm where they cause cellular damage by oxidizing a variety of biologically important molecules, including DNA, proteins and lipids. Proteins are key molecules that play the ultimate role in various structural and functional aspects of living organisms. Free radicals and reactive oxygen and nitrogen species may react with proteins leading to oxidative modifications of proteins such as protein hydro-peroxides formation, hydroxylation of aromatic groups and aliphatic amino acid side chains, nitration of aromatic amino acid residues, oxidation of sulfhydryl groups, conversion of amino acid residues into carbonyl groups, cleavage of the polypeptide chain and formation of cross-linking bonds ${ }^{5}$.

One of the unique features of protein oxidation by a wide variety of routes is the generation of carbonyl groups ${ }^{6}$. Protein carbonyl accumulation is an indicator of oxidative damage during aging in cells and tissues ${ }^{7,8}$. The aim of the present study was to determine the relationship between human age and protein oxidation in erythrocyte membranes measured in terms of the protein carbonyl group in a healthy Indian population; and to study the relationship between total plasma antioxidant potential and protein oxidation.

\section{MATERIALS AND METHODS}

\section{Selection of subjects}

The study was carried out on 49 normal healthy subjects of both sexes between the ages of 17 and 80 years. The criterion for selecting subjects was the same as that described earlier ${ }^{9}$. Briefly, the subjects were screened for diabetes mellitus, asthma, tuberculosis, and other major illness. None of the subjects were smokers or were taking any medication. All persons gave their informed consent for the use of their blood samples for the study. The protocol of study was in conformity with the guidelines of the Allahabad University Institutional Ethical Committee.

\section{Collection of blood, isolation of plasma and membrane preparation}

Human venous blood from each volunteer was obtained by venipuncture in heparin. The blood was centrifuged at $1800 \mathrm{~g}$ for $10 \mathrm{~min}$ at $4{ }^{\circ} \mathrm{C}$. After the removal of plasma, buffy coat, and approximately upper $15 \%$ of the packed red blood cells (RBCs), the RBCs were washed twice with cold PBS $\left(0.9 \% \mathrm{NaCl}, 10 \mathrm{mM} \mathrm{Na} \mathrm{HPO}_{2}\right.$, $\mathrm{pH}$ 7.4). Erythrocyte ghosts from leucocyte-free RBC's were prepared by osmotic shock procedure ${ }^{10}$. 


\section{Determination of membrane protein carbonyls}

Erythrocyte membrane protein carbonyls were measured according to the procedure of Levine et al. ${ }^{11} .0 .2 \mathrm{ml}$ erythrocyte membrane samples in PBS were taken in two tubes as test and control. $4.0 \mathrm{ml}$ of $10 \mathrm{mM}$ 2,4-dinitrophenylhydrazine (DNPH) prepared in $2 \mathrm{M} \mathrm{HCl}$ was added to the test sample and $4.0 \mathrm{ml}$ of $2 \mathrm{M} \mathrm{HCl}$, alone was added to the control sample. The contents were mixed thoroughly and incubated for 1 hour in the dark at $37^{\circ} \mathrm{C}$. The tubes were shaken intermittently every $10 \mathrm{~min}$ to facilitate the reactions with proteins. After that, 20\% TCA (w/v) was added to both tubes and the mixture left in ice for $10 \mathrm{~min}$. The tubes were then centrifuged at 3,500 rpm for $20 \mathrm{~min}$ to obtain the protein pellets. The supernatant was carefully aspirated and discarded. The protein pellets were washed three times with ethanol: ethyl acetate $(1: 1, \mathrm{v} / \mathrm{v})$ solution to remove unreacted DNPH and lipid remnants. Finally protein pellets were dissolved in $6 \mathrm{M}$ guanidine hydrochloride and incubated for $10 \mathrm{~min}$ at $37{ }^{\circ} \mathrm{C}$. The insoluble materials were removed by centrifugation. The carbonyl content was determined by taking the spectra of the supernatant at $370 \mathrm{~nm}$. Each sample was read against the control. The carbonyl content was calculated by using an absorption coefficient (e) of $22,000 \mathrm{M}^{-1} \mathrm{~cm}^{-1}$ and the data were expressed in $\mathrm{nmol} / \mathrm{mg}$ protein. The erythrocyte membrane protein content was determined by the method of Lowry et al. ${ }^{12}$, using BSA as standard

\section{Determination of total antioxidant capacity}

The total antioxidant capacity measured in terms of Ferric Reducing Ability of Plasma (FRAP) values were determined following the method of Benzie and Strain ${ }^{13}$. Working FRAP reagent was prepared by mixing acetate buffer (300 mM, pH 3.6), 2, 4, 6- tri [2-pyridyl]-s-triazine $(10 \mathrm{mM}$ in $40 \mathrm{mM} \mathrm{HCl})$ solution and $\mathrm{FeCl}_{3} \cdot 6 \mathrm{H}_{2} \mathrm{O}$ (20 mmol/1) solution in 10:1:1 ratio respectively. $3 \mathrm{ml}$ of FRAP reagent was mixed with $100 \mu$ of plasma; the content was stirred vigorously to mix the contents thoroughly. The absorbance was read at $593 \mathrm{~nm}$ at the interval of 30 seconds for $4 \mathrm{~min}$. Aqueous solution of known $\mathrm{Fe}^{2+}$ concentration in the range of 100-1000 $\mu \mathrm{mol} /$ liter was used for calibration. Using regression equations, the FRAP values ( $\mu$ mol Fe (II) per liter) of the plasma was calculated.

\section{Statistical analysis}

Statistical analyses were performed using the software PRISM 4 (Graph pad Software Inc., San Diego, CA). The relationships among the various parameters were assessed using the Pearson correlation coefficient $(r)$.

\section{RESULTS}

Like most biological membranes, the plasma membrane of erythrocytes is extremely rich in proteins. Owing to this unique feature, membrane proteins of aging erythrocytes are primary targets for ROS and RNS ${ }^{14,15}$. Erythrocyte membrane protein carbonyl content was found to increase in an age-related pattern indicating an increase in oxidative protein damage in elderly subjects (Fig. 1). In view of the significant age-dependent decline in plasma antioxidant capacity measured in terms of FRAP reported by us earlier ${ }^{4}$, the comparison of protein carbonyls and total antioxidant capacity of plasma reveal a significant relationship (Fig. 2). We found a significant negative correlation between protein carbonyl levels and plasma FRAP values in the current study.

\section{DISCUSSION}

For many years, lipid peroxidation has been the focus of investigation, but due to their relatively high abundance it is now recognized that proteins are the main targets for

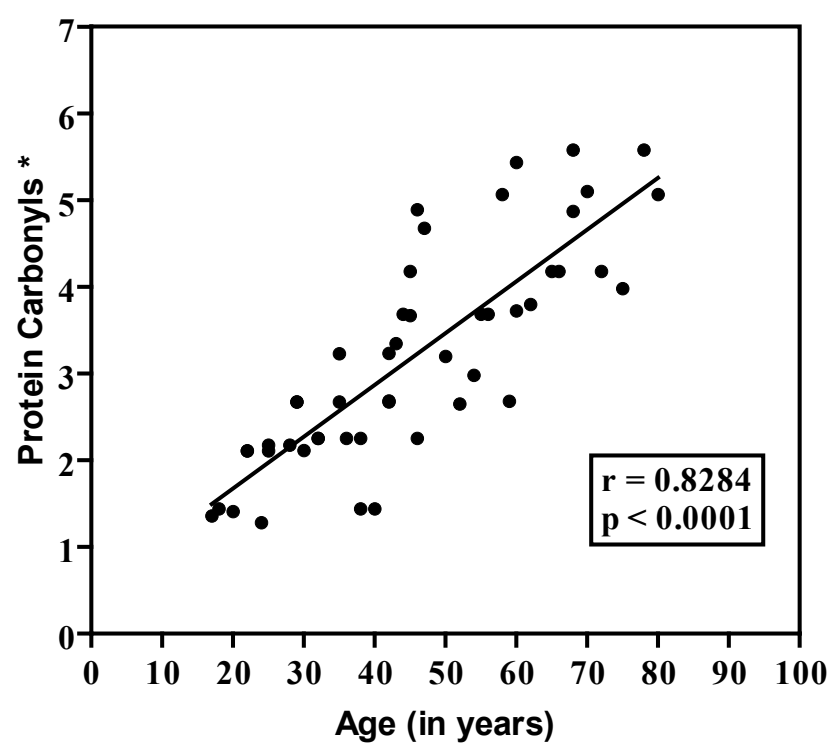

Fig. 1. Erythrocyte membrane protein carbonyls (protein oxidation index) plotted as a function of human age. * Protein carbonyl groups expressed as nmoles/mg protein. $\mathrm{p}<0.0001 ; \mathrm{r}=0.8284$.

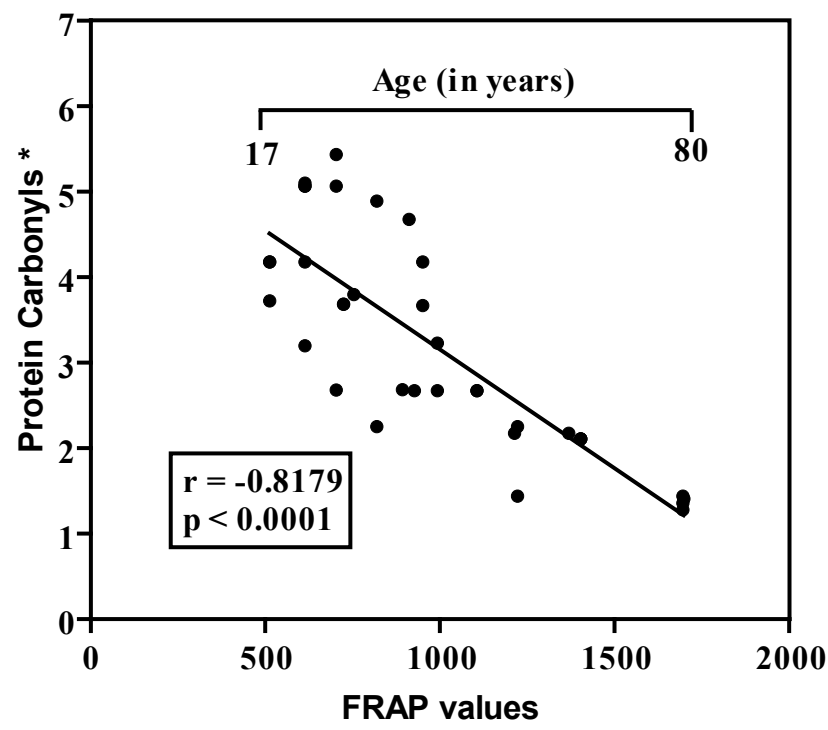

Fig. 2. Correlation plot between protein carbonyls (protein oxidation index) and total antioxidant capacity of plasma (measured as FRAP). Number of protein carbonyl groups expressed as nmoles/ mg protein. FRAP values expressed as $\mu \mathrm{mol} \mathrm{Fe}$ (II) per liter of plasma. $\mathrm{P}<0.0001 ; \mathrm{r}=-0.8179$. 
cellular oxidants. Considerable evidence indicates that the maintenance of protein redox status is of fundamental importance for cellular function, therefore changes in redox homeostasis of proteins are considered to be among the molecular mechanisms leading to endothelial dysfunction $^{14,15}$. Most reactive oxygen species in living organisms are produced as by-products of many metabolic processes. Since ROS are extremely reactive, they interact with virtually all cellular components principally modifying their properties ${ }^{16}$ and thus are believed to play a key role in the aging process ${ }^{17}$. Studies have suggested an important role of reactive oxygen species and reactive nitrogen species (RNS) in the formation of oxidatively modified proteins found in aged tissues ${ }^{18,19}$ and plasma ${ }^{14,15}$.

Evidence also shows the importance of by-products of lipid peroxidation process such as reactive aldehydes in the occurrence of many oxidatively modified proteins. Membrane lipid peroxidation, which increases with increasing human age as reported by us earlier ${ }^{4}$, is an autocatalytic chain reaction and many of its products, including hydroxynonenal and hydroxyhexanal, are themselves very potent damagers of proteins ${ }^{20}$. Protein carbonyl groups may be introduced in membrane proteins by secondary reaction of the nucleophilic side chains of cysteine, histidine, and lysine residues, and reactive aldehydes produced during the peroxidation of membrane lipids $^{21}$. On the other hand, current knowledge indicates that the measurement of protein carbonyl groups may have some advantages over lipid peroxidation products because of the relatively early formation and stability ${ }^{21}$. Our observation of a significant negative correlation between protein carbonyl levels and plasma FRAP values in the current study may be explained by the possible redox homeostasis between plasma and erythrocyte membrane proteins. There are no established data or explanations in the current literature as to why the redox status cannot be efficiently balanced in plasma and erythrocyte membrane proteins in aging.

Age-related increase in the carbonyl content of proteins from other tissues has also been identified and it has been estimated that approximately $20-50 \%$ of the total protein is oxidized in aged humans ${ }^{22}$. The accumulation of protein carbonyls following oxidative stress and during aging suggests an age-related imbalance with respect to the generation of a range of different ROS, antioxidant defense mechanisms and the normal protein turnover mechanisms of the cell.

Normal human red blood cells (RBC) survive in the circulation for approximately 115 days after they are released from the bone marrow. This suggests the existence of a molecular "alarm clock" to measure cell age, and the eventual generation of a signal for removal of senescent cells by the reticuloendothelial system ${ }^{23}$. RBCs have an extensive antioxidant system designed to eliminate the formation of ROS. Hydrogen peroxide $\left(\mathrm{H}_{2} \mathrm{O}_{2}\right)$ produced by autoxidation of hemoglobin is a predominant ROS in RBCs. The role of the membrane in the formation of $\mathrm{H}_{2} \mathrm{O}_{2}$ and the resultant heme degradation products can be explained by the known binding of hemoglobin to the cytoplasmic end of band 3 on the RBC membrane ${ }^{24}$.
Hydroxyl radical-generating reactions may result from the $\mathrm{H}_{2} \mathrm{O}_{2}$-catalyzed oxidation of ferrous iron, which normally is bound to protein in the ferric state ${ }^{25}$. If the formation of $\mathrm{H}_{2} \mathrm{O}_{2}$ on the membrane surface is not scavenged immediately by antioxidant defense enzymes, the extensive formation of hydroxyl radicals may cause oxidation of membrane proteins to protein carbonyls. Increased membrane-bound protein carbonyl load may set an internal alarm clock for earlier time.

Oxidative modification of erythrocyte membrane protein is considered very significant in view of their important role in transport, enzyme activity and membrane fluidity. Reports show that protein carbonylation increases with the age of cells, organelles, and tissues of varied species and the introduction of carbonyl groups into amino acid residues of protein is a characteristic of oxidative modification. Protein carbonylation has also been linked to age-dependent wear and tear of specific enzymes, such as aconitase and the adenine nucleotide translocase ${ }^{26,27}$. In elderly persons the erythrocyte membrane proteins are the most damaged by carbonylation ${ }^{28}$ and the age dependent increase in the carbonylation of RBCs proteins may further initiate the formation of advanced glycated end products (AGEs). In diabetes, an age associated disease, AGE-proteins of the RBCs membrane interact with specific receptors and contributes towards the augmented adhesion of erythrocytes ${ }^{29,30}$. Some major age related diseases linked with increased carbonylation include Parkinson's disease, Alzheimer's disease, cancer, cataractogenesis, diabetes and sepsis ${ }^{31-33}$. The correlation between antioxidant capacity and oxidative damage during aging has been reported in several tissues in different species $^{34,35}$. The antioxidant status is considered to play an important role in counteracting the detrimental effects of age-associated free radical hyper production and oxidative stress $^{36}$.

\section{CONCLUSION}

The found increased erythrocyte membrane protein oxidation in terms of protein carbonyls during aging in humans; together with a positive correlation between erythrocyte protein carbonyls and plasma FRAP values strongly support the presence of increased oxidative stress during aging. The elevated erythrocyte membrane carbonyl levels observed with increasing age in this study may be viewed as a biomarker for aging. Therefore, the reduction in plasma FRAP activity as well as in its protective activity on redox homeostasis of erythrocyte membrane proteins could negatively affect the health status of the elderly.

\section{ACKNOWLEDGEMENTS}

The authors declare having no conflict of interest. 


\section{REFERENCES}

1. Sohal RS, Weindruch R. Oxidative stress, calorie restriction and ageing. Science 1996;273(5271):59-63.

2. Yu BP, Yang Y. A critical evaluation of free radical theory of aging, A new proposal for the Oxidative stress hypothesis. Ann NY Acad Sci 1996;786:1-11.

3. Ashok BT, Ali R. The aging paradox: free radical theory of aging. Exp Gerontol 1999;34(3):293-303.

4. Rizvi SI, Maurya PK. Markers of oxidative stress during aging in humans. Ann NY Acad Sci 2007;1100:373-82.

5. Berlett BS, Stadtman ER. Protein oxidation in aging, disease and oxidative stress. J Biol Chem 1997;272(33):20313-6.

6. Mirzaei H, Regnier F. Enrichment of carbonylated peptides using Girard $\mathrm{P}$ reagent and strong cation exchange chromatography. Anal Chem 2006;78(3):770-8.

7. Chaudhuri AR, De Waal EM, Pierce A, Van Remmen H, Ward WF, Richardson A. Detection of protein carbonyls in aging liver tissue: A fluorescence-based proteomic approach. Mech Ageing Dev 2006;127(11):849-61.

8. Adachi H, Fujiwara Y, Ishii N. Effects of oxygen on protein carbonyl and aging in Caenorhabditis elegans mutants with long (age1 ) and short (mev-1) life spans. J Gerontol A Biol Sci Med Sci 1998;53(4):240-4.

9. Rizvi SI, Jha R., Maurya, PK. Erythrocyte plasma membrane redox system in human aging. Rejuvenation Res 2006;9(4),470-4.

10. Marchesi VT, Palade GE. The localization of Mg-Na-K activated adenosine triphosphate on red cell ghost membranes. J Cell Biol 1967;35(2):385-404.

11. Levine RL, Garland D, Oliver CN, Amici A, Climent I, Lenz AG, Ahn BW, Shaltiel S, Stadtman ER. Determination of carbonyl content in oxidatively modified proteins. Methods Enzymo 1990; $186: 464-78$

12. Lowry OH, Rosebrough NJ, Farr AL, Randall RJ.. Protein measurement with the Folin phenol reagent. J Biol Chem 1951;193:265-75.

13. Benzie IFF, Strain JJ. The ferric reducing ability of plasma (FRAP) as a measure of "Antioxidant Power": The FRAP assay. Anal Biochem 1996;239(1):70-6.

14. Topçuoglu A, Uzun H, Balci H, Karakus M, Coban I, Altug T, Aydin S, Topçuoglu D, Cakatay U. Effects of estrogens on oxidative protein damage in plasma and tissues in ovariectomised rats. Clin Invest Med 2009;32(2):133-43.

15. Cakatay U, Aydin S, Yanar K, Uzun H. Gender-dependent variations in systemic biomarkers of oxidative protein, DNA, and lipid damage in aged rats. Aging Male 2010;13(1):51-8.

16. Lushchak VI. Free radical oxidation of proteins and its relationship with functional state of organisms. Biochem (Mosc) 2007;72(8):809-27.

17. Chakravarti B, Chakravarti DN. Oxidative modification of proteins: age-related changes. Gerontology 2007;53(3):128-39.

18. Stadtman ER. Protein modification in aging. J Geront 1988;43(5):112-20.
19. Warner HR, Starke-Reed P. Oxidative stress and aging. In: Clerch LB, Massaro DJ, editors. Oxygen, gene expression and cellular function. New York: Maecel Dekker Inc, 1997.p.139-67.

20. Halliwell B, Gutteridge JMC. Free Radicals in Biology and Medicine. $3^{\text {rd }}$ ed. Oxford: Oxford University Press; 1999.

21. Dalle-Donne I, Rossi R, Giustarini D, Milzani A, Colombo R. Protein carbonyl groups as biomarkers of oxidative stress. Clin Chim Acta 2003a;329:23-38.

22. Stadtman ER. Protein oxidation and aging. Science 1992;257(5074):1220-4.

23. Franco RS. The measurement and importance of red cell survival. Am J Hematol 2009;84:109-14.

24. Nagababu E, Mohanty JG, Bhamidipaty S, Ostera GR, Rifkind JM Role of membrane in the formation of heme degradation products in red blood cells. Life Sci 2010;86:133-8.

25. Stadtman ER. Protein oxidation and aging. Free Radic Res 2006;40:1250-8.

26. Yan LJ, Levine RL, Sohal RS. Oxidative damage during aging targets mitochondrial aconitase. Proc Natl Acad Sci USA 1997;94(21):11168-72.

27. Yan LJ, Sohal RS. Mitochondrial adenine nucleotide translocase is modified oxidatively during aging. Proc Natl Acad Sci USA 1998;95(22):12896-901.

28. Constantin A, Constantinescu E, Dumitrescu M, Calin A, Popov D. Effects of ageing on carbonyl stress and antioxidant defense in RBCs of obese Type 2 diabetic patients. J Cell Mol Med 2005;9(3):683-91.

29. Chappey O, Dosquet C, Wautier MP, Wautier JL. Advanced glycation end products, oxidant stress and vascular lesions. Eur J Clin Invest 1997;27(2):97-108.

30. Wautier JL, Paton RC, Wautier MP, Pintigny D, Abadie E, Passa P, Caen JP. Increased adhesion of erythrocytes to endothelial cells in diabetes mellitus and their relation to the vascular complications. N Engl J Med 1981;305(5):237-42.

31. Levine RL. Carbonyl modified proteins in cellular regulation, aging, and disease. Free Radic Biol Med 2002;32(9):790-6.

32. Dalle-Donne I, Giustarini D, Colombo R, Rossi R, Milzani A. Protein carbonylation in human diseases. Trends Mol Med 2003b;9(4):169-76.

33. Smith MA, Rudnicka-Nawrot M, Richey PL, Praprotnik D, Mulvihill P, Miller CA, Sayre LM, Perry G. Carbonyl-related posttranslational modification of neurofilament protein in the neurofibrillary pathology of alzeimer's disease. J Neurochem 1995;64(6):2660-6.

34. Inal ME, Kanbak G, Sunal E. Antioxidant enzyme activities and malondialdehyde levels related to aging. Clin Chim Acta 2001;305(1-2):75-80

35. Melov S. Animal models of oxidative stress, aging, and therapeutic antioxidant interventions. Int $\mathrm{J}$ Biochem Cell Biol 2002;34(11):1395-400.

36. Meydani M. Dietary antioxidants modulation of aging and immuneendothelial cell interaction. Mech Ageing Dev 1999;111(2-3):12332. 